\title{
THE SIXTH AMENDMENT AND THE RIGHT TO GOUNSEL
}

\section{RHEA Kemble Brecher $\dagger$}

The sixth amendment is vitally important and necessary, but $I$ believe that it contains a limited privilege. Attempts to extend the sixth amendment from beyond this limited sphere have generated difficulties and controversies. The sixth amendment reads:

In all criminal prosecutions, the accused shall enjoy the right to a speedy and public trial, by an impartial jury of the State and district wherein the crime shall have been committed, which district shall have been previously ascertained by law, and to be informed of the nature and cause of the accusation; to be confronted with the witnesses against him; to have compulsory process for obtaining witnesses in his favor, and to have the Assistance of Counsel for his defence. ${ }^{1}$

The first phrase, "[i]n all criminal prosecutions," indicates that sixth amendment rights commence only at the initiation of an adversary proceeding, be it by indictment, arraignment, or criminal complaint. They are not implicated in the investigatory or the grand jury phase. ${ }^{2}$ The sixth amendment guarantees that the defendant will have someone with her who understands the procedural rules, the rules of evidence, and who can give her other professional assistance.

No language in the sixth amendment refers to the defendant's right to counsel of choice. Some courts of appeal, however, have found some kind of qualified right, or limited right, to counsel of choice. ${ }^{3}$ The

$\dagger$ Executive Assistant United States Attorney for the Southern District of New York. This Article is adapted from a presentation given at the Symposium on Right to Counsel, March 1, 1988.

1 U.S. ConsT. amend. VI.

${ }^{2}$ See Kirby v. Illinois, 406 U.S. 682, 688 (1972) (plurality decision) ("In a line of constitutional cases in this Court ... it has been firmly established that a person's Sixth ... Amendment right to counsel attaches only at or after the time that adversary judicial proceedings have been initiated against him.").

${ }^{3}$ See e.g., United States v. Panzardi Alvarez, 816 F.2d 813, 816 (1st Cir. 1987) ("The denial of a defendant's right to choose his own counsel jeopardizes his sixth amendment guarantees . . . ."); United States v. Koblitz, 803 F.2d 1523, 1527 (11th Cir. 1986) ("It has long been recognized that a criminal defendant has a right to retain counsel of his choice."). 
Supreme Court has said little on this subject, but what it has said arguably limits the concept of counsel of choice. In Morris $v$ Slappy, ${ }^{4}$ the Court held that the sixth amendment does not include the right to a "'meaningful relationship' between an accused and his counsel." In Morris, the court assigned a public defender to an indigent defendant. This defender became ill shortly before the trial date and could not continue representation. The court appointed a substitute public defender and asked him if he needed a continuance. The substitute counsel responded that he felt prepared to go to trial. The defendant viewed the situation differently, however, and pushed for a continuance. The court declined to give him a continuance, and the defendant later complained of ineffective assistance of counsel. ${ }^{6}$ The Supreme Court affirmed the conviction. ${ }^{7}$ I believe that Morris stands for the proposition that a defendant does not have the right to choose her appointed counsel. This proposition is borne out in actual practice. When an indigent defendant needs counsel, this counsel is appointed and not selected. The defendant cannot choose.

There are two interesting exceptions to this general rule. The military gives a broader right: in military proceedings, the defendant can choose her military counsel, subject only to the limitation that counsel be "reasonably available." A second possible exception can be found in United States $v$. Monsanto, now vacated pending a rehearing en banc by the Second Circuit. ${ }^{9}$ In that case, a panel of the Second Circuit stated that if the government established the probability that the defendant's assets would be forfeited, those funds could only be used to pay attorney's fees at Criminal Justice Act ("GJA") rates. ${ }^{10}$ This could lead to a defendant's right to select CJA counsel.

Another limitation on any notion of a right to counsel is economic. Individuals who are ineligible for appointed counsel can only choose among affordable counsel. For example, if I were arrested, I may wish to be represented by some of the private lawyers who are participants in this Symposium. However, on a government salary, I would have difficulty paying their fee. I would have a very limited right to choose my counsel. Certainly the sixth amendment does not guarantee that a defendant must be able to choose her counsel, regardless of cost.

Sixth amendment rights are also limited when the scheduled trial

461 U.S. 1 (1983).

- Id. at 14 .

- See id. at 4-9.

7 See id. at 15.

8 See 10 U.S.C. $\S 838(b)(3)(B)(1982)$.

- 836 F.2d 74 (2d Cir. 1987), reh'g granted, Jan. 29, 1988.

${ }^{10}$ See id. at 85. 
date conflicts with the attorney's calender. Similarly, the defense attorney cannot have a conflict of interest in the case. For example, counsel cannot represent another defendant in the case, unless all parties waive this right after a proper disclosure. ${ }^{11}$ Counsel must be admitted to practice in the particular court and finally, and most importantly, counsel must be willing to accept the assignment. Ultimately, counsel must want to represent the defendant.

Congress recently passed the Comprehensive Forfeiture Act of $1984,{ }^{12}$ which allows the federal government to impose forfeiture of property on those convicted of a felony. ${ }^{13}$ The statute lists particular assets that are subject to forfeiture: First, physical items used to facilitate a crime are subject to forfeiture. ${ }^{14}$ For example, a yacht that was used to transport drugs would fall under the Act. ${ }^{16}$ Second, particular monies or assets traceable as proceeds of a crime also fall under the Act. ${ }^{16}$ For example, if a wholesale drug dealer pays her connection with a rare ruby, which could be identified because of its configuration, that particular ruby would be subject to forfeiture.

Two procedural safeguards protect items potentially subject to forfeiture. First, the government does not arbitrarily decide that items should be subject to forfeiture. A grand jury must evaluate specific items and conclude that there is probable cause to believe that the items in question are subject to forfeiture. Second, the grand jury evaluation also represents a determination, at least in federal cases, that the prosecutor believes a prima facie case exists to prove forfeitability. According to Department of Justice guidelines, ${ }^{17}$ a prosecutor should not seek an indictment unless she believes she has a prima facie case.

When the indictment is returned, the prosecutor asks the court for a restraining order to prevent the transfer of assets such as the yacht, the ruby, and all assets totaling $\$ 2,000,000$, or enough assets to cover the $\$ 2,000,000$ potential judgment. Defense counsel is likely to attend the arraignment of a prospective client and say "I am not appearing in this case; rather, I am here to make an application. I would be interested in appearing, but only if the client can pay me. The client can

11 See Model Rules of Professional Conduct Rule 1.7 (1987).

12 Pub. L. No. 98-473 $\S \S 303-09$, 98 Stat. 1837, 2044-51 (codified in scattered sections of 21 U.S.C.).

13 See id. $\$ 303,98$ Stat. at 2044 (codified at 21 U.S.C. $§ 853$ (Supp. IV 1986)). 1986)).

14 See id. $\S 306(a), 98$ Stat. at 2050 (codified at 21 U.S.C. $§ 881$ (a)(7) (Supp. IV

1s See United States v. One 28' Int'l Vessel, 741 F.2d 1319, 1320 (11th Cir. 1984).

16 See United States v. Littlefield, 821 F.2d 1365, 1387 (9th Cir. 1987).

17 See 38 Crim. L. Rep. (BNA) 3007 (Oct. 1, 1985). 
only pay me by using the items that are subject to forfeiture-the yacht, the ruby, and the $\$ 2,000,000$." Of course, the defense lawyer must clearly state that she is not appearing, because once the counsel has "appeared," the judge can keep counsel in the case regardless of the counsel's wishes.

For a long time, I believed that the government's position was hopeless since defense counsel could use the right to counsel requirement to shield tainted assets from forfeiture. Two recent cases, United States $v$. Harvey, ${ }^{18}$ and the Monsanto case in the Second Circuit, have given the government encouragement. In Harvey, the court said that there is no sixth amendment right to use potentially forfeited assets to pay one's attorney. ${ }^{19}$ Consequently, the state has no obligation to fund a defense at the fee rate of private counsel. The Second Circuit panel opinion in Monsanto arrived at essentially the same holding, but allowed that funds could be used to pay an attorney at C.JA rates. The Second Circuit stated that there must be a hearing at which the government proves, "by evidence independent of the indictment, a probability of convincing a jury beyond a reasonable doubt both that the defendant has violated the statute and that the assets are subject to forfeiture." ${ }^{20}$ If the government meets this burden, then the assets cannot be used to retain a private attorney, "except to the extent of allowing the payment of attorney's fees at CJA rates from the restrained assets."21

These cases raise the issue of whether there is any sixth amendment right to use the proceeds of crime to pay for a lawyer. Although the defense bar would probably disagree with my formulation of this question, consider its application to a bank robbery situation. Certainly the proceeds of this criminal action should not be used to pay for a criminal defense attorney. An old story told about Clarence Darrow vividly illustrates this issue. Darrow is in his office. He hears some commotion from the street and the cries of a bank guard. The bank guard bursts into Darrow's office and declares that the bank was robbed, but, fortunately, the thief took a satchel of money that contains a dye packet that will explode and stain the money red. The bank guard leaves. Shortly thereafter, a man enters Darrow's office. He hands Darrow a satchel of money. It is stained red. The man says, "Mr. Darrow, I need to speak to you. I have this funny feeling that I am going to be investigated in connection with a bank robbery." Darrow replies, "Wait a minute. Would you please take that satchel, leave 
this office, and walk around the park three times." The man says, "No, no! I've got an urgent problem. I am going to be investigated for a bank robbery!" But Darrow insists that the man go walk around the park three times. The man does what Darrow asks, and when he returns to Darrow's office, Darrow agrees to represent him. He hands Darrow the money, and asks: "By the way, why did you ask me to walk around the park?" Darrow replies, "Well, I didn't want to take freshly stolen money."

While the story is obviously apocryphal, it does raise the important question of whether Darrow should have taken the money. Did Darrow have an obligation to call the police when the man first came in? What should Darrow do if the bank guard comes to the office and asks for the money back? Obviously, Darrow cannot keep the money in the face of the bank's superior claim. The same is true in a case involving a car theft. Someone who steals a car and is later arrested cannot sell the car and use the assets to pay for a defense attorney. Obviously, the owner should have a prior claim to the car.

The harder question is: Would the lawyer have a better claim than the government to proceeds of narcotics activity because it is less tangible than a car? The result should be the same, especially if there is a procedural safeguard such as the one that the Second Circuit offered in Monsanto. ${ }^{22}$ The government has no obligation to pay for more expensive representation. How does this undercut the sixth amendment? Are defendants left in a helpless position if they are represented by appointed counsel?

Those who argue that the Forfeiture Act undercuts the sixth amendment make the unwarranted assumption that appointed counsel is incompetent counsel. If that were true, then clearly indigent people who have never made large amounts of money from narcotics activity have been badly represented in violation of their sixth amendment rights. An examination of public defenders' practical experience points out that this is not the situation.

I am told that the actual rate of pay for Federal Defenders is around $\$ 60,000$. This approaches the maximum pay rate for an Assistant U.S. Attorney, which is about $\$ 72,000$. Both prosecution and defense lawyers are willing to work at the same general rate of pay. Additionally, it has been my experience in New York that many members of the Federal Defenders' Unit are more experienced than Assistant U.S. Attorneys. There seems to be less turnover among Federal Defenders than among Assistant U.S. Attorneys. Accordingly, they have

${ }^{22}$ See id. at 83 . 
far more trial experience than many, if not most, of the Assistant U.S. Attorneys. At least in New York, the same can be said about attorneys from the Criminal Justice Act Panel. My personal experience has been that many of these attorneys are ex-prosecutors or ex-legal aid lawyers. Some are partners in "Wall Street" firms. They are lawyers who are more than adequate to represent clients. Rather than engraft an additional right on to the sixth amendment-the right to counsel of choice-we should be concerned with the compensation of appointed counsel in order to ensure that defendants receive competent appointed counsel.

Benefactor payments create sixth amendment problems. They arise in crime organizations, because the organization has a strong incentive to keep all of its members legally well represented. The organization wants to ensure at all costs that the goals of an individual coincides with the goals of the organization. No one should be allowed to cooperate with and to provide information to the government.

The sixth amendment looks backward because it assumes a completed crime: the person under indictment is being prosecuted for a past crime, and is afforded counsel with respect to these acts. In cases involving individuals in a crime organization, however, the criminal activity has been caught in midstream. Coconspirators continue the crime. Even with their criminal proceeds, lower level members of a crime organization are not wealthy, so they receive a great financial benefit when the organization provides legal representation for them. This arrangement strongly discourages the lower members from cooperating with the government. Whether it is true or not, the client will believe that her actions will be reported to the organization by the attorney. In crime organizations, reports of cooperation with the government may lead to the client's death. Additionally, the lawyer herself may have an economic incentive to argue against client cooperation. If she encourages or even permits her client to cooperate, she will never be retained by that organization again.

Of course, this is not a problem encountered only by lawyers who represent members of violent crime organizations. Counsel for members of corporations face the same problem in white collar grand jury investigations. If a corporation and its officers and employees are subject to investigation, the corporation generally will offer to pay for representation of the officers and employees. In actual practice, however, the lawyer chosen by senior management to represent the corporation finds counsel for the less senior members of the corporation. When the lawyer for the corporation refers business to a colleague, this colleague will implicitly know that if her client hurts the position of the corporation 
or the senior management, she will be unlikely to receive another referral from that lawyer. This inherent economic conflict threatens the lawyer's relationship with her client.

The solution to this problem seems to be full and frank discussion between the lawyer and client at their first meeting. This discussion should include the lawyer's potential conflicts. Should the lawyer say to her client, " $75 \%$ of my business comes from this particular drug organization, and I dare not risk losing that business"? Should the lawyer say, "I have only recently started my own practice, and this referral from General Motors or General Electric means a great deal to me and I hope to get some referrals in the future'? I doubt that conversations such as these take place. But while establishing rapport between the attorney and her client is difficult, a proper attorney-client relationship demands such initiation. The atiorney should say to the client at the outset:

I am here to protect your interests zealously within the confines of the law. The law puts certain limits on me. There are some communications that are confidential, and I will hold them confidential. I will provide other communications, which are not confidential, to the government if I am subpoenaed. For instance, should you choose to retain me, the amount of your fee, the method by which you pay me, and perhaps our discussions about the fee, can be disclosed. Know that up front. Similarly, if you are engaged in an ongoing crime and you consult me about how to execute that crime, I will not help you in that. But, if we are talking about past charges placed against you, you may confide in me, and everything, including the facts relating to the crime-if indeed there was a crime committed and you committed it-will not be disclosed for any reason. If subpoenaed, I will not respond and, if held in contempt, I will go to jail.

These should be the ground rules. If all counsel accepted and followed them, then no particular lawyer would be disadvantaged. Clients could not shop for a lawyer since they would discover that all lawyers would approach the issue in the same way. The solution to this problem will come when lawyers as a group establish and maintain clear and unassailable standards. 
